\title{
The Implementation of Sinking Illegal Fishing Vessels Policy Towards the Bilateral Relations between Indonesia and Malaysia
}

\author{
M. Adnan Madjid National Defense University, Indonesia \\ Widodo AMCS Research Center, Indonesia \\ Eko G. Samudro National Defense University, Indonesia
}

\begin{abstract}
This study discusses the policy implementation by Indonesia regarding the sinking of illegal fishing vessels towards Indonesia's bilateral relations with Malaysia, especially those that occurred in Tarakan and Nunukan. Many losses from illegal fishing by neighboring countries made the President of Indonesia, through the Ministry of Maritime Affairs and Fisheries, took a firm stance regarding the rules of ship sinking to the accused ships that have been proven doing illegal fishing in the Indonesian sea. The Ministry of Maritime Affairs and Fisheries together with relevant agencies helped implement the policy which had an impact on the relationship between Indonesia and Malaysia. In this case, Malaysia is still in third place after Vietnam and the Philippines in the data on the number of vessels destroyed by the Indonesia. Malaysia is also the country with the fifth largest fish commodity production in Southeast Asia whereas fish consumption in Malaysia is ranked first in the region. Thus, the country faces obstacles in fulfilling the need for fish faced with Indonesian policies in addressing illegal fishing arrests by foreign countries. By qualitative methods, this research reveals the background of the existence and implementation of policies for the sinking of illegal fishing vessels and the impact of these policies on the Malaysian state. International system pressure, state power and other theories were used to help carry out this research. As a result, this study provides an overview of the relationship between Indonesia and Malaysia after the enactment of the policy. First, the Malaysian increase their fish trade and sea safeguard with Indonesia, both in the designated sea area and the gray area. Second, the government of Malaysia adopted the sinking ships method due to its mechanism that is considered effective and efficient in creating detterence effect. Third, both countries agreed to release poor or small fishermen who carry out IUU Fishing made between the President of Indonesia and the Prime Minister of Malaysia.
\end{abstract}

Keywords

Illegal Fishing; Maritime; Security; Indonesia; Malaysia

\section{INTRODUCTION}

Indonesia as a country that is fully

M. Adnan Madjid is a lecturer in Faculty of National Security, National Defense University. His focus research on National Security Policy and the National Defense System. E-mail: adnan.madjid@idu.ac.id. Widodo is a researcher at AMCS Research Center Indonesia. His research field is related to Maritime Strategic Management and Conflict Resolution. E-mail: widodo@gmail.com.

Eko G. Samudro is a National Security Faculty staff, National Defense University. Some of my research is related to Conflict Resolution in the Border Region. Email: ekogsamudro@gmail.com. sovereign in its maritime sector by restoring the glory of the sea that was once enjoyed by this archipelago is an aspiration to be realized by the President of Indonesia, Joko Widodo. The commitment stated in the document of Vision-Mission by Jokowi-JK Action Program that is to prioritize the identity of 
Indonesia as an arcipelagic country in enhancing Indonesia's maritime security and building international cooperation which is included in one of the main priorities in Indonesia foreign policy. In addition, the commitment in building the maritime economy is also one of the main agendas of The President, Joko Widodo. Out of the nine points in the maritime economic development program, the third point the reads the eradication of illegal, unregulated and unreported (IUU) Fishing (Widodo \& Kalla, 2014).

The Ministry of Maritime Affairs and Fisheries (KKP) led by Minister Susi Pudjiastuti received an honor in carrying out the mission launched by President Joko Widodo. Under her leadership, the ministry became the backbone of the eradication of illegal fishing vessels in Indonesia Sea Area with the help from other related institutions such as, The Indonesia Navy, Marine Security Agency (BAKAMLA), Water Police (POLAIR) and Attorney's Office who are included as the member of 115 Task Force (SATGAS 115).

In a plan to restore Indonesia's sea glory, it was motivated by state losses in the maritime sector caused by IUU Fishing for years (Chapsos \& Hamilton, 2018). Figures from the Food and
Agriculture Organization (FAO), Indonesia suffered losses of Rp. 30 Trillion (Detik Finance, 2015). In handling illegal fishing cases, the ministry of MAF took a firm approach by arresting illegal fishing actors and drowning its ships. Recorded form October 2014 to August 2018, the MAF Ministry has sunk m488 ships with 272 Vietnamese ships, 90 Filipino ships, 23 Thai Ships, 25 Indonesian ships, 2 Papua New Guinea ships, 1 Chinese ship, 1 Belize ship, 1 Nigerian ship and 73 Malaysian Flagged ships (PSDKP, 2018).

Basically, Indonesia - Malaysia has a settlement mechanism that has been agreed if there are fishermen from one of the countries entering the sea area that has not been agreed upon by the two countries. The act will be taken by law enforcement officer from the two countries at sea if they find fishermen entering the gray area by giving warnings and evictions. This is summarized in the Memorandum of Understanding between The Government of Indonesia and Malaysia concerning the General Guidelines on Fisheries Handling by the Law Enforcement Institutions in the Republic of Indonesia and Malaysia year 2012 (Pratomo, 2016). This agreement was made on January 27, 2012 in Bali 
and strengthened by a joint statement between the two countries signed by Prime Minister Mohd Najib bin Tun Abdul Razak and President Susilo Bambang Yudhoyono in Putra Jaya on December 18, 2012.

The sinking of ships carried out by Indonesia is to eradicate IUU Fishing in its waters. However, this policy is not only afffected illegal fishing, bu also the Malaysian State which was the origin of several foreign ships that the Government of Indonesia drowned. In 2018, the Ministry of Maritime Affairs and Fisheries, through its 115 Task Force, has drowned 125 ships in August 2018. (Sutriyanto, 2018). Which details, 18 ships in Pontianak, 6 ships in Cirebon, 15 ships in Bitung, 3 ships in Aceh, 7 ships in Belawan, 1 ship in Merauke, 40 ships in Natuna, 1 ship in Ambon, 9 ships in Batam, 23 ships in Tarempa and 2 ships in Tarakan. Previously, in 2015 the Indonesian Navy also sank 3 foreign ships in Tarakan. This number is certainly decreasing from 127 ships sunk in 2017 ago.

Based on the previous explanation and supported by relevant theories, this study aims to analyze the background of the emergence of policies related to the sinking of IUU Fishing ships and the current impact of the IUU Fishing ship's action on the bilateral relation between Indonesia and Malaysia.

\section{RESEARCH METHOD}

Based on the Memorandum of Understanding between the Government of the Republic of Indonesia and the Government of Malaysia in Respect of the Common Guidelines Concerning Treatment of Fishermen by Maritime Law in 2012, it is stated that the act of warning and expulsion in finding fishermen entering the grey area. However, this MoU was not generally understood by some fishermen or even institution. Some of them did not know the exact borderline between the countries due to the lack of GPS tool and it made them caught breaking the law. This study uses qualitative descriptive research design. There are several characteristics the exist in the qualitative methodology, which are: (1) Objectives aimed at providing an in-depth understanding of the social world where research participants live including their socialmaterial conditions, experiences, perspectives and history; (2) Recording the meaning from the research subject; (3) Observing social life from the side of the process rather than the static side; (4) 
Providing a holistic perspective of what is studies. Then, the data analysis used being explained; and (5) Doing effort in was done by the method from Miles, providing an objective assessment of what Huberman, and Saldana. According to is being studied (Snape \& Spencer, them, qualitative data analysis can 2003). present descriptions that are used to find

In other words, this research uses a a stable and accountable relationship in method that can be used to analyze the social phenomena. In these techniques, action of results of a social order, data collection will lead to data especially within the maritime presentation (data display) and data community, which is interpreted into a condensation in the framework of policy formulation that affects government conclusions. Due to the flexible qualitative units in other regions, which in the research style, these four processes can context of this study the Malaysian State. be done intermittently differ from the From several events that are considered to quantitative style (Miles, Huberman, \& represent the entire phenomenon of Saldana, 2014).

fishing arrests in the Indonesia sea area, researchers are trying to interpret the meaning contained there and put it into an objective analysis. In addition, several implications of the prosecution of ship sinking for illegal fishers which have an impact on Malaysia are also the object of analysis of social values that are the result of such action. The method described earlier also explains interactions that influence each other form research variables. In the future, based on the analysis, a situation that might occur later can be explained and developed into an interrelated research.

Data were obtained from interviews with several informants and literature

\section{RESULT AND DISCUSSION}

\section{The Background of IUU Fishing vessels} sinking policy in Indonesia

The rise of IUU Fishing in Indonesia and Malaysia has made the governments of the two countries in making the best policy to overcome this problem. For Indonesia, the sinking was chosen as an action to deal with illegal fishing in its water. There are many factors that encourage Indonesia to sink ships, one of which is domestic political factors. The domestic political factor according to neoclassical realism is the internal political condition of a country which is a determining element of the country's 
public policy (Foulon, 2015). Important elements in domestic factors according to neoclassical realism are political and economic ideology, national character, political partisan and socioeconomic structure (Rose, 1998).

Considering at Indonesia's economic structure, Indonesia is still synonymous with the characteristics of developing countries. Indonesia's GDP (Gross Domestic Product) per ca-pita reaches USD 3,570, compared to Singapore which is considered as the progressed country in Southeast Asia with GDP's number of 52,960 USD per year. That is why, the politics in Indonesia is colored by the debates regarding how to improve the wealthy of its people. When viewed from existing natural resources such as petroleum, agricultural products, forest products, and other earth resources, the sea is one of the most interesting areas to be explored. In the midst of limited resources available in the Indonesian archipelago and unstable world oil prices, the Indonesian sea is still able to provide sustainable food sources if it is managed properly (Febrica, 2017). Not only quantity excellence with a vast sea area, various types of fish in Indonesia also provide its own value for Indonesian fishery commodities in the eyes of the world.

Taking into account its geographical location, Indonesia is actually surrounded by resourceful waters, both mineral resources and fisheries resources. Indonesia itself has an EEZ area of $6,025,110 \mathrm{~km} 2$ plus $99,360 \mathrm{~km} 2$ of water on land (FAO, 2013). From these territorial waters, the Gross Value of Fisheries Output (GVFO) in Indonesia in 2004 was USD 5.468 million. The majority of these figures represent the contribution of the capture fish sector which reached USD 3,130 million (FAO, 2006). Basically, Indonesia is actually able to boost the country's income figure from the above value. This can only be done if Indonesia manages to eradicate IUU fishing from its waters. From this vast sea area, the seas in northern Indonesia become a red zone for the threat of IUU fishing. In addition to Malaysian ships, several MCHs from Vietnam, the Philippines and Thailand also often operate in the area. Moreover, the area is also an area that is often used as a fishing spot by Chinese MCHs. The increasing sea security in this area is more important because it is not only for the purpose of deterring IUU fishing, but also to be aware of the escalation of conflict in the 
South China Sea adjacent to the seas in northern Indonesia.

The limited number of GVFO in Indonesia can be caused by several factors. The magnitude of the figure contributed by the capture fish sector in GVFO makes this sector need more attention to analyze the determinants of the government's difficulties in increasing the GVFO number. The first elements that influence income from the capture fish sector are weather and sea waves. The geographical position clamped to the Asian and Australian continents as well as the tropical climate that makes Indonesia occupied areas are always rained throughout the year, making the ocean waves in this area very difficult to predict (The Weather Company, 2012), especially in transitional seasons. These factors sometimes disrupt fisheries activities in Indonesia. For example, the price of Squid in Probolinggo once reached IDR 60,000 per kilogram from the normal price of only IDR 35,000 in August 2017 (Fahmi, 2017). Another occurrence of sea commodity price increases that have occurred was in October 2017 in Pangkal Pinang when prices rose for salted squid (from IDR 70,000 to IDR. 100,000), Kerisi Fish (from IDR 50,000 to IDR 70,000), and
Mackerel Fish (from IDR. 60,000 to IDR. 90,000 (Artiana, 2017). Both of these examples occur for one and the same reason, bad weather that forces fishermen not to go to the sea, causing a reduced supply and rising prices of fish.

Another factor besides the weather that can affect fish supply in Indonesia is the practice of IUU fishing. This factor is more of a concern for the public and the government because the cases are more predictable and "easy" to be handled. In addition, the estimated loss from IUU fishing can also be mapped by state agencies authorized for maritime security. One of them is the KKP which, through Minister Susi, stated that Indonesia's losses due to IUU fishing reached Rp. 3000 trillion. When compared with weather management for fishing activities, the government must spend a very large amount of money to build technology that can predict nature properly. With the gap in technological development and the ability to do finance research and development projects, the process of establishing quality $R$ \& $D$ in Indonesia to be able to support such programs requires a long time. In addition to weather forecasting technology, the government must also be able to produce large-scale fishing vessels on a large scale to facilitate 
fishermen to go to sea even in bad awareness of maritime national identity is weather conditions.

manifested in the activities of fishing by

Moreover, there are still many the Indonesian people, especially those fishermen in Indonesia who use living close to the sea. Discourse traditional ways to go to the sea, although collaboration and understanding of sophisticated fishing boats can be knowledge also contributed to produced, training in the use of modern encouraging fishermen in Indonesia to tools will not be easily implemented. In come down to the sea (Octavian \& other words, the public in Indonesia is Yulianto, 2014).

more realistic to ask the government

So, it is not surprising that shipping directly about its priority programs in technology and navigation science are eradicating IUU fishing rather than highly developed in the archipelago's seeking ways to fight nature.

Indonesia's maritime superior maritime glory to make the identity of the programs had experienced a decline, especially since the New Order regime which focused more on infrastructure development on land. In addition, the arrival of the colonialist people in ancient times to the archipelago also had a negative impact on marine activities until now. According to C.P.F. Luhulima, the Netherlands has left a defensive force on the coastline to fight the British fleet in Indonesia, rather than rival the strength of the British naval forces by building its own fleet (Personal communication, 21 September 2018). Based on the identity as a maritime nation, collective feelings and shared ownership are accumulated dynamically to manifest in the actions of maritime society even more indisputable. Unfortunately, this golden age cannot be maintained until today until Indonesia's marine condition is far from being able to sustain the welfare of its people.

In its technical order, the commitment to reestablish Indonesia's maritime glory is poured into the ideals of the world's maritime axis. This idea was conveyed by Joko Widodo in the Presidential Candidate debate on June 22, 2014 in a debate on International Politics and National Resilience (2014). In other words, President Joko Widodo's various efforts in eradicating IUU fishing in Indonesia are part of a great ideal to make Indonesia the world's maritime axis.

Attention to maritime security that the Indonesian people. In other words, was incorporated into the real program of 
high-level political constellation results as demonstrated by President Joko Widodo has not been found in Malaysia. In addition, the Malaysian public currently wants the government to be able to resolve security issues in the South China Sea area as soon as possible. According to the researcher of the Institute of Strategic and International Studies Malaysia, Muhammad Sinatra, the issue of maritime security has attracted greater attention from the Malaysian public considering Malaysia is one of the claimant states in the region (Personal communication, 21 September 2018). So, it's no wonder that the initiation of eradicating IUU fishing in Southeast Asia was initiated by Indonesia, not Malaysia or other countries. In short, the paradigm used in maximizing Indonesia's marine resources is by safeguarding the Indonesian sea to ensure Indonesian fishermen can sail safely until fisheries production increases. In addition to increasing the production of Indonesian fishery commodities, the sinking of ships also aims to create an environmentally friendly fishing industry. With such a friendly way, it is expected that the sea in Indonesia will be able to provide sustainable fish supplies for a long time.
However, the Government of Indonesia must also remain open-minded to evaluate this policy. With the possibility of amending a law, in fact various other alternatives can be considered in line with the changing reality in the field. Seeing the condition of Indonesian fishermen who are still using small vessels, the Indonesian Government may be able to allocate seized vessels that have been used for illegal fishing to small fishermen in various parts of Indonesia. Of course, this must be equipped with a training mechanism related to the use of the ship and monitoring of who the ship is given. In addition, the CTF has also been working with the local government, universities or even fishermen groups on the distribution of seized vessels. With regard to grants or the provision of ships to certain groups, this must pass the mechanism in the court and be decided to become state property and can then be given to other parties to be utilized. However, there is a weakness if the ship is given to a third party or even the party that gets the item through an auction. First, those who get the ship will feel burdened for the cost of repairs and maintenance of the ship.

Furthermore, the operational costs are also considered high considering that the 
ships obtained are not commonly used vessels. Second, the bidding process itself can also be a gap for cheating even from the Indonesian businessmen themselves.

Based on information from one of the informants, illegal fishing vessels that have been auctioned may no longer be used for fishing activities, in other words must be converted into other vessels. However, it is often found that vessels that have been auctioned operate to catch fish again or even resell them to their original owners from foreign countries, of course with higher prices. This is the concern of the Ministry of Maritime Affairs and Fisheries who chose the vessel auction to not be a priority.

Therefore, a mechanism for supervision, evaluation and severe sanctions are needed in relation to the utilization of vessels provided by the state to third parties. However, the use of seized vessels from illegal fishing can also facilitate Indonesia's bargaining position in the eyes of Malaysia. What makes this effort rather difficult is the difference in the classification of poor fishermen in Indonesia, which is lower than Malaysian poor fishermen. With the facilities provided by the government in the form of seized ships, the poor Indonesian fishermen will be able to be upgraded. If this is the case, the agreement between Indonesia and Malaysia to uniformize the classification of fishermen will be easier.

The Impact of Ship Sinking Policy in Indonesia to Malaysia

Indonesia's policy to sink the ships used in IUU fishing practices has affected the countries of origin of these vessels. One of the biggest impacts was Malaysia, where the number of Malaysian-flagged vessels ranked 3rd after Vietnam and the Philippines as KIA, which was most often sunk by the Indonesian Government. To explain how this policy impacts Malaysia, neoclassical realism provides an explanatory framework in the concept of state power. According to neoclassical realism, a state has national power that cannot be fully utilized by the government in authority due to technical limitations. Things that might be a barrier in utilizing national power are limited human resources, technology, natural factors, funding, and so forth. From the limited national power, the government can only use state power to realize various policies formulated. So, in this study the forces of Indonesia and Malaysia which are the object of discussion are the strength of the state or relative ability of national forces 
that can be used by the government in running the country.

Basically, Indonesia and Malaysia are actually able to boost the country's income value from the above GVFO value. This can only be done if the two countries successfully eradicate IUU fishing from their waters. Even Malaysia could double the country's GVFO to double, considering the loss from IUU fishing of USD 1.443 million (or equivalent to RM 6 billion), not much different from the Malaysian GVFO figure that dwells on the figure of USD 1.416 million.

However, eradication of IUU fishing in Indonesia is still constrained by several things. Some of the obstacles that are still often faced are limited ship fuel for longstanding/long-standing patrols in the sea, synergies between marine security components, and also the strong physical foreign crew. Even among foreign foreigners from Thailand have martial arts and immune science (Youtube, Najwa Shihab's personal communication with Rear Admiral TNI Widodo, 11 February 2015). In addition, the criminal chain of IUU fishing in Indonesia has also been organized and difficult to trace to its roots (Youtube, Najwa Shihab's personal communication with Susi Pudjiastuti, 11 February 2015).
After the implementation of the Indonesian Government's ship sinking policy, it was noted that the fishermen (NTN) exchange rate in Indonesia increased (Raharjo et al, 2018). According to data from Word Data News and Research, from January 2014 to July 2016, only July 2014-December 2014 NTN dropped dramatically. After the Indonesian Government sank the IUU fishing vessel (December 2014), NTN slowly increased to reach its highest value in this period at 109.7 in July 2016 (Data, 2016).

In addition to improving the welfare of Indonesian fishermen, this policy also makes Malaysia more difficult to meet the needs of fish in the country. According to Colonel Laut (E) Rolly Stephanus Rore, Marine Defense Attache of the Indonesian Embassy in Kuala Lumpur, there are at least four impacts of the sinking of illegal fishing vessels by Indonesia on the Malaysian fishing industry: (1) rising fish prices on the market due to declining yields catch; (2) employers in capture fisheries attempt to equip navigation equipment and detection on fishing vessels so as not to enter Indonesian territory; (3) some fisheries entrepreneurs who usually catch fish around the waters of the Malacca Strait choose to move to 
fishing areas around the eastern coast waters of the Peninsula, Labuan and Kota Kinabalu, Sabah; and (4) Malaysian fishing boat crews (ABK) who are Malaysian citizens choose to work in other fields, and the majority are replaced by foreign nationals, especially Indonesian workers (TKI) (Interview, 15 September 2018)

The increase in fish prices in Malaysia as a result of the sinking of ships by the Government of Indonesia is also in accordance with Minister Susi's statement. Minister Susi said, "Fish prices in Singapore and Malaysia are starting to rise, because costs are increasing. That means this is an advantage for Indonesian exporters to be able to export fresh fish which cannot be done so far (Ariyanti, 2014). In addition to fulfilling fish supply by eradicating IUU fishing, Malaysia can also search for fishery products from other countries. With Malaysia's limited economic power as mentioned earlier, it is rather difficult for Malaysia to explore looking for fish exporters from outside the Southeast Asian region.

From the above explanation it can be concluded that the strength of the Indonesian and Malaysian states to eradicate IUU fishing in order to bring prosperity to the people is still constrained by several factors. The national strengths of the two countries in the geographical location, maritime resources, and fisheries industry cannot yet be fully maximized due to limited apparatus, weather, economic capital, and security stability (Satria \& Matsuda, 2004). Therefore, the actions taken by the Indonesian Government which are actually directed at eradicating IUU fishing have an impact on the Malaysian State which at the same time is trying to maximize the strength of its country in the maritime sector to meet the needs of its domestic fish.

International pressure urging the eradication of IUU fishing in Southeast Asia has made Indonesia initiate the sinking of ships for illegal fishing as a breakthrough. The innovation to eradicate IUU fishing with the sinking of the perpetrator's ship has begun since the administration of President Susilo Bambang Yudhoyono with the making of Law Number 45 of 2009 concerning Fisheries. In fact, with this legal basis, 250 ships that mostly operate around the Natuna Islands have been sunk by detonation with Molotov cocktails (Politik Indonesia, 2014).

Although the sinking was intended to create a deterrence effect, the Indonesian government must also look to the 
diplomatic norms to avoid Government's policy in carrying out law misunderstandings from parties outside enforcement at sea. (Interview, 21 Indonesia. In other words, diplomatic September 2018).

communication must still be upheld in

The world's positive response to law enforcement so as not to invite other Indonesia's success in handling illegal problems from foreign parties. In addition, fishing provides a pilot model to the Indonesian Government must be neighboring countries, including Malaysia. careful in using its military instruments in the IUU fishing eradication mission which can be misinterpreted by the international community as a military action.

In fact, what really happened in Malaysia shortly after the Indonesian Government sank the IUU fishing vessel according to the Malaysian Embassy in Kuala Lumpur is that, the Malaysian government respects the law enforcement efforts at sea carried out by the Government of Indonesia. At the beginning of the implementation of the policy of sinking foreign fishing vessels proven to have carried out illegal fishing in Indonesian waters in 2014, the Malaysian Government through the Malaysian Minister of Foreign Affairs expressed concern about the Government of Indonesia's policy. However, after the Indonesian Government explained to the Malaysian Government by inviting relevant Malaysian officials, the Malaysian Government could understand and subsequently respect the Indonesian In Malaysia where the federal system is implemented, all maritime issues are the responsibility of the federation or the central government. Marine issues regulated in the constitution include fishing vessels, shipping and navigation in the high seas and inland waters, ports, lighthouses, shipping safety standards, and coastal management. Only sea turtle management is recorded, which in writing is the responsibility of the state (Constitution of Malaysia).

The sinking of ships by Malaysia against KIA responding IUU fishing in the sea must be anticipated by Indonesia. These needs to be done considering that there are still many Indonesian fishermen who violate Indonesian-Malaysian territorial waters due to several reasons, one of which is the neglect of GPS technology. Even this sinking could be a means of the Malaysian state's "revenge" when several Gemilang Line flagged ships were blown up in Indonesia. This argument is based on historical facts 
where Indonesian authorities will carry out patrols to arrest Malaysian fishermen who carry out illegal fishing in Indonesia after news of Indonesian fishermen being caught by TLDM (Malaysian Navy Army) (Kresno Buntoro, personal communication, 27 September 2018)

In addition, there are several acts of cheating that often carried out by the Malaysian side by capturing Indonesian fishermen who are fishing in the gray area with traditional tools. Meanwhile, if Malaysian fishermen who catch fish with trawls are captured by Indonesia in the gray area, the Malaysian side asks for an expulsion rather than arrest. This is certainly not commensurate with Malaysia's treatment of Indonesian fishermen.

The complexity of law enforcement over the agreement between Indonesia and Malaysia is basically rooted in unclear boundaries. Kresno Buntoro explained that Indonesia-Malaysia had just agreed to the border of the continental shelf in the Malacca Strait. While the EEZ boundary between Indonesia and Malaysia in these waters has no agreement (personal communication, 6 September 2018). While awaiting the process of determining the Indonesia-Malaysia EEZ boundary,
Patkor (Coordinated Patrol) is routinely carried out by the Indonesian Navy and TLDM, especially after the implementation of ship sinking in Indonesia (Ardian, personal communication, 6 September 2018). The desire to maintain maritime security by joint patrols was also shown at the ministerial level of the two countries that were committed, not only to conduct patrols, but also to exchange satellite and radar information (KKP, 2016). However, once again, the unfinished agreement has created confusion in the order of officers who often do not know the agreement that has been made by officials from both countries (Kresno Buntoro, Interview, September 6, 2018).

However, the increasingly intense Indonesian-Malaysian trade interaction in marine commodities is actually a mutually beneficial relationship. With an adjacent geographical location, fishery products imported by Malaysia can be reduced in price compared to similar products that Malaysia imports from other countries that are further away. Indonesia's high exports to Malaysia are also determined by a sluggish fishing market due to very low fish consumption in Indonesia. In other words, Indonesian products that do not find a domestic market will be transferred to Malaysia and other fish importing 
countries such as Europe which have especially regarding the classification of more demand and more promising prices. poor/small fishermen. If this has been

In the end, for the common good, done, the agreement that has been made Indonesia-Malaysia agreed to not make it must be thoroughly disseminated to the difficult for small fishermen who were less officers in the field, even to the smallest able to follow the dynamics of fishing detail. This must be done to avoid regulations in both countries. Recently confusion between officers in the sea who President Joko Widodo with Prime are on duty.

Minister Najib Tun Razak agreed to release fishermen captured by both countries (Ten, 2017). Prime Minister Najib Tun Razak said, "We realize that these fishermen are poor and it is unfair for us to close their livelihoods" (Bernama, 2017). It is hoped that from this agreement, the fishermen can return to their families, continue their lives, and do not violate the boundaries of the two countries for the second time. Even so, Nurul Dewi Saraswati said that this agreement is a general agreement that tends not to make it difficult for fishermen who have a mediocre life (Personal communication, 12 September 2018).

Therefore, the Indonesian-Malaysian Government must immediately complete its maritime boundary agreement so that the national legal jurisdiction of each country can be carried out appropriately. In addition, the two countries must create uniform standards for some details of the agreements that have been made, did not enter Indonesian waters when

\section{CONCLUSION}

Thus, the IUU fishing vessel sinking policy is carried out because of the many losses and damage caused by IUU fishing to make the fishing community suffer and the Indonesian State cannot enjoy the potential of its marine resources. In addition, the sinking of the ship was carried out to provide a deterrent effect on the perpetrators. The reason was finally mixed in national politics which emphasized that Indonesia's glory in the sea was important to be put forward so that the welfare of the Indonesian people in general could be improved.

In addition, the policy of sinking ships in Indonesia in general did not cause serious tensions with the Malaysian state, but this also resulted in (1) reduced supply and rising fish prices in Malaysia, (2) increasing awareness of Malaysian fishermen by installing their GPS so that did not enter Indonesian waters when 
fishing, (3) the migration of Malaysian fisherman fishing areas to the northern sea of Sabah-Serawak which did not directly contact the Indonesian maritime border, and (4) the increasing number of Indonesian migrant workers working in Malaysian fishing industry due to the large number of ABK Malaysian citizens who change professions because of the higher risk of going to sea. In addition, in addressing this policy, Malaysia also continues to increase fish trade and safeguard marine areas from illegal fishing with Indonesia, both in designated marine areas and in disputed areas / gray areas. Furthermore, Malaysia also adopted a ship sinking method because the mechanism was considered effective and efficient in creating deterrence effects to the perpetrators with limited maritime security capabilities available and made an agreement with Indonesia to release poor or small fishermen who did IUU fishing made between the Indonesian President and Malaysian Prime Minister.

\section{REFERENCES}

Ariyanti. (2014). Menteri Susi bikin harga ikan di Singapura \& Malaysia Mahal? Retrieved from http://bisnis.liputan6.com/read/2141 507/menteri-susi-bikin-harga-ikan-di- singapura-amp-malaysia-mahal in 12th Sep 2018.

Artiana, S. (2017). Harga Ikan Asin Di Pangkalpinang Naik. Retrieved from https://babel.antaranews.com/berita/6 5445/harga-ikan-asin-dipangkalpinang-naik in 9th Sep 2018. Chapsos, I., \& Hamilton, S. (2018). Illegal fishing and fisheries crime as a transnational organized crime in Indonesia. Trends in Organized Crime, 1-19.

Detik Finance. (2015, Maret 13). Malaysia kekurangan ikan, Menteri Susi: Laut mereka kecil. Retrieved from https://finance.detik.com/beritaekonomi-bisnis/2858018/malaysiakekurangan-ikan-menteri-susi-lautmereka-kecil in November 17th, 2018.

Fahmi, M. (2018). Wuzz, Angin Kencang, Harga Ikan Naik. Retrieved from

https://www.jawapos.com/radarbrom o/read/2017/08/09/6464/wuzzangin-kencang-harga-ikan-naik in 9th Sep 2018.

FAO (2006). The Republic of Indonesia. Retrieved from http://www.fao.org/fi/oldsite/FCP/en/id n/profile.htm in 10th Sep 2018 
FAO (2013). Fishery and aquaculture country profiles; Indonesia. Retrieved from

http://www.fao.org/fishery/facp/IDN/e n in 10th Sep 2018.

Febrica, S. (2017). Maritime security and Indonesia: Cooperation, interests and strategies. Routledge.

Foulon, M. (2015). Neoclassical realism: challengers and bridging identities. International Studies Review, 174), 635-661.

KKP. (2016). Malaysia Ingin Impor Ikan Lebih Banyak Dari Indonesia. Retrieved from http://news.kkp.go.id/index.php/mala ysia-ingin-impor-ikan-lebih-banyakdari-indonesia/ in 13th Sep 2018.

Miles, Huberman \& Saldana. (2014). Qualitative Data Analysis. A Method Sourcebook. SAGE Publications: LA. London.

Octavian \& Yulianto. (2014). Budaya, identitas, \& masalah keamanan maritime. Jakarta: Unhan.

Politik Indonesia. (2017). Era SBY, 250 kapal asing ditenggelamkan pakai Molotov. Retrieved from http://politikindonesia.com/index.php? $\mathrm{k}=$ politisiana\& $\mathrm{i}=63527$ Era\%20SBY,\%20250\%20Kapal\%20
Asing\%20Ditenggelamkan\%20Pakai \%20Molotov in 15th Sep 2018.

Pratomo, E. (2016). Indonesia-Malaysia maritime boundaries delimitation: a retrospective. Australian Journal of Maritime \& Ocean Affairs, 8(1), 7384.

PSDKP. (2018). Personal data from Kasubdit Penanganan Barang Bukti dan Awak Kapal, 12th September 2018.

Raharjo, A., Sudrajat, T., Bintoro, R. W., \& Saefudin, Y. (2018). The sinking ship policy to the perpetrator of illegal, unregulated and unreported fishing in criminal law perspective. In E3S Web of Conferences (Vol. 47, p. 06002). EDP Sciences.

Rose, G. (1998). Neoclassical realism and theories of foreign policy. World

Satria, A., \& Matsuda, Y. (2004). Decentralization of fisheries management in Indonesia. Marine Policy, 28(5), 437-450.

Snape, D., \& Spencer, L. (2003). The foundations of qualitative research. Qualitative research practice; a guide for social science students and researchers. (J. Ritchie, \& J. Lewis, Penyunt.) London: SAGE Publication. Sutriyanto, E. (2018). 488 Kapal Pencuri Ikan sudah Ditenggelamkan, 


$\begin{array}{lr}\text { Mayoritas Berbendera Vietnam. } \\ \text { Retrieved } & \text { from }\end{array}$

www.tribunnews.com/regional/2018/

08/20/488-kapal-pencuri-ikan-

sudah-ditenggelamkan-mayoritas-

berbendera-vietnam in September 2018.

The Weather Channel. (2012). How Weather Affect Fish Activity. Retrieved from https://weather.com/sportsrecreation/fishing/news/weatheraffects-fish-activity-20120328 in 10th Sep 2018.

Widodo, J., \& Kalla, J. (2014). Visi misi dan program aksi. Indonesia. 